\begin{tabular}{c} 
Journal of Business School \\
$2018,1(2): 47-59$ \\
DOI: $10.29226 /$ TR1001.2018.92 \\
Journal Homepage: https://www.journalbusiness.org \\
\hline
\end{tabular}

\title{
Role of Islamic Micro Credit Activities of Akhuwat in Poverty Alleviation in District Nowshera
}

\author{
Asad Khan \\ Department of education, University of Haripur, Khyber Pakhtunkhwah, Pakistan \\ asadadamzai@yahoo.com
}

\section{Dr. Khalid Naveed}

Assistant Professor Department of Agricultural Sciences, University of Haripur, Khyber Pakhtunkhwah, Pakistan, k_naveed1974@yahoo.com

\section{Mahnaz Iqbal Yousafzai}

PhD Scholar, Department of Education, Northern University Nowshera, Khyber

Pakhtunkhwah, Pakistan, mahnazyousafzai@yahoo.com

\section{Kifayat Khan}

Lecturer Department of Education, University of Haripur,Khyber Pakhtunkhwah, Pakistan, Kifayatkhan@uoh.edu.pk

\begin{abstract}
The study entitled " Role of Islamic Micro Credit activities of Akhuwat in poverty Alleviation in District Nowshera " was carried out to find the role of micro credit activities of Akhuwat in poverty alleviation in tehsil Nowshera. Details about the respondents were taken in written form from the local and branch offices of Akhuwat. Sample of respondents consisted of 100 male and 50 females. A questionnaire was developed in two parts. Part A was to find out the main characteristics of the respondents. Part B was about the operational and financial activities of Akhuwat. Data was collected from 150 respondents comprising 100 males and 50 females through questionnaire. The data was analyzed through SPSS version 17 . Results of the analyzed data showed remarkable role of Akhuwat in poverty alleviation. Social status of the respondents has been improved after taking loan. Their health, education. savings. purchasing power, decision making power, income and capitals have been improved. Hence micro credit activities of Akuwat in District Nowshera has a positive relationship with poverty alleviation. It was suggested that the government must cooperate with Akhuwat so maximum benefits may be achieved. Government must also start such activities at the doorsteps of the loan takers.
\end{abstract}

Keywords: Islamic Microcredit, Akhuwat, Poverty Alleviation. 


\section{Introduction}

The impact of micro credit reduces the poverty through highly self-employment and producing good income. It helps the poor to get sustainability in the socio-economic, educational and health consequences. Micro Credit has a positive effect on the children of borrowers (Nathanael Goldberg, 2005) Micro Credit is sometimes called micro lending which is given to the poor for self- employment. The poor people increase their living standards by investing these small loans in some activities (Fernando, 2006). Micro Credit has been proved as an important tool for poverty alleviation and uplifting the living of poor. Micro Credit is mainly an observable innovation in poverty alleviation in the last half century. Due to high running costs the interest rate of micro credit s very high as compared to other banks (Nawai, 2010). The high rate of interest of micro credit can be reduced by novelty, effectiveness and by attractive selling rivalry (Fernando, 2008).

Poverty is a common issue to all the nations of the world. It is a multidimensional problem. Poverty occurs when most of the citizens of a country are lacked of their basic rights and needs. There may be some social, economical and political problems which hurdles the poverty but education and awareness are considered to be the fundamental requirement to cope with this giant problem. Pakistan is also facing the problem of poverty. Hussien and Hussain (2003) suggest that increasing the opportunity of micro credit would ultimately reduce poverty. The society plays a pivotal role in the development of the locality and the best of the society is to provide the schemes which reduce the level of poverty (Lindvert, 2006).

Micro Credit is considered as a vital tool of poverty reduction. The importance of microcredit was seriously felt in 80's after when Yunus introduced Grameen Bank for micro credit. The aim of micro credit was to reach the poor and needy people. The basic purpose of micro credit is to provide small loans to those poor people who are not able to reach the formal system of loans. These small loans help in poverty reduction (Otero, 1999). No external guarantor was required for these loans. A group of few individual was made and each member of the group has to serve as a guarantor of the other member. The group responsibility and repayments of loans in due time made it easy to qualify for the loans (Chaudhuri, n.d). The interest rate of these loans was very high. This was because of the small amounts for a short period of time (Fernando, 2006). The major drawback of this credit was that the bank was at far flung distance from the rural areas (Bakhshoodeh and Karami, 2008).

\section{Review of Literature}

Many micro credit institutions were set up after the realization that it is a short way to cope with the poverty. This has changed the formal system of banking and opened a new era of banking (Delfiner and Peron, 2007). Governments and different NGOs are using micro credit as a tool for reducing poverty (Llnto, 2003). The money provided as micro credit to the low income people is utilized in business activities for the improvement of life standards (Nawai, 2010).

The main functions of micro credit are as follow:

1. Ending exploitation of poor

2. Easy provision of loans

3. Ease in repayment of loans

4. Self -employment

5. Reduction of poverty 
Pakistan is an agricultural country and mainly depends upon agricultural products. Pakistan is facing a giant problem of poverty. It is due to lack of income and human resources. Different steps have been taken to eradicate poverty but all these struggles went fruitless. In the recent decade micro credit has been showing tremendous achievements against the poverty. Different NGOs and banks are providing micro credit to the poor. Presently a number of institutions such as NGOs, private firm and government sponsored rural programs are providing micro credit to the poor people of the country. Khyber bank, First women bank, Khushali bank, First Micro Finance bank and Akhuwat are providing loans to the poor. Employment is the basic right of the every citizen but if there is no employment then the best way to reduce the unemployment is to provide the small loans to these citizens to make them empowered (Yunus, 2006).

Erik Thorbecke (2004) has pointed out many issues related to poverty. He has also pointed out the causes of permanent poverty that why people remain in that state. He has also discussed various types of poverty. Inequality is the main source of poverty. Naryan and Petech (2002) have declared that every strategy of poverty reduction must be initiated from the poor. When the poor are heard and ivetigated carefully then it is easy to resolve the problem by simply investing in poor people assets and capabilities.

Atif Jamil (2006) considers the poverty as a socio-economic problem of Pakistan after executing that one third of its population is living beyond the poverty level. He has pointed out the most susceptible groups of people such as children, workers, Women and religious minorities.

M. Sharif (2006) has pointed out poverty among the several issues in Pakistan. Pakistan has started the Millennium Development Goal of eradicating the poverty by 2015. Pakistan's claim of the rate of poverty reduced cannot be justified by any measure and tool according to Asian Development Bank and United Nations Development Program.

Hoque (2008) has suggested micro credit as a powerful tool for the poverty alleviation. It has been observed that micro credit increases the income of the poor. More and more and more resources are mobilized. Investments are increased and hence the living standards are improved.

Marr (2004) has pointed out that due to the high rate of interest on micro credit; the repayment has become a burden the poor people. The process may be made as easy as to the poor. Basher (2009) has considered agriculture sector the most beneficial for the poverty alleviation. Micro credit in agricultural sector enhances the chances of investments. Agricultural sector is a vast field and several sub categories and employment opportunities are mostly available in it. Khan et al (2007) conducted research on short term loans to the farmers and suggested that farmers must avail this loan in time to meet their needs.

Mason and Smith (2003) concluded that micro credit is very essential to the women empowerment. Most of the poor women do not directly participate in jobs. They have free time at their homes and they can easily accommodate in small business by providing them small loans for short interval of time. Irobi (2008) pointed out that micro credit has been proved fruitful in the context of small business and women participation in this regard has been excellence. The utilization and repayments of these loans have shown a tremendous result upon women. Shastri (2009) said that micro credit is the best solution of poverty reduction but the process to access the credit is very complicated. The poor do not able to access the small loans in appropriate time. The process must be made such that almost all the poor can easily obtain the loan opportunity, so that poverty can be eradicated.

Momoh (2005) has pointed out that useful and successful micro credit systems are operating in rural areas along with some obligations from the government. The government must legalize 
the process of credit according to the needs of the poor. Latife (2003) also stated that poor people are in high risk of poverty. They are still facing hardships in obtaining the small loans. Ahmad \& Naveed (2004) experimented the role of micro credit in the field of poverty and found that a positive relationship between micro credit and income. The credit provided to the poor by Khushali Bank has raised the life standard and working capital.

Waheed (2009) concluded that micro credit has improved the income. Morduch (2002) has examined the impact of micro credit and found that micro credit has raised the standard of life in several aspects such as size of the family, health and education. Low income developing countries always faces severe problem of poverty and micro credit works as a weapon against poverty in these countries (Akram \& Hussain, 2011). Micro credit plays an important role in the rural areas where there is little access the formal banks for loans. It is anticipated that micro credit must be used as a fundamental source of investment for the rural fabrication actions to enhance the conditions of poor people. Micro credit is not expected to be used for daily expenditure. Micro credit is also offered to the low income poor (Seemi, 2009). Developing countries have adopted several policies through which an ordinary individual can access to the micro credit and can run his/her business for the betterment of the country (Beck et al.2008). Despite of these efforts and conveniences most of the poor do not reach these micro credit institutions (Chodhury, 2009).

Pakistan is a developing country and mainly depends upon agricultural products. Due to insufficient resources hardly Pakistan can produce agricultural products which fulfill the needs of $50 \%$ of the local people. (SBP-a,2007). Savings are always lower than the consumption in Pakistan. In order to fill the gap between saving and consumption government of Pakistan introduces micro credit loans. Micro credit is a new phenomenon yet it proving to be an excellent tool for development (Haroon, Jamal 2008).

Micro credit facilities are open to poor as well as middle level people in Pakistan. Micro credit loans are unique in their nature. It is not offered in the conventional manner. The main purpose of these loans is to get full benefits of the loans. These loans are offered in the collectoral form in which each borrower is the guarantor in the same group (Bajwa, 2001). Pakistan is facing an extreme level of poverty. The government as well as the inhabitants of Pakistan is capable to meet the challenging situation of poverty. The people have strong commitment and ideas to fight against poverty. It is very difficult to alleviate the poverty from top to bottom. Poverty must be eradicated from the grass-root level. Micro credit is somewhat a best choice for the poverty alleviation. Poor of Pakistan can well utilize the loans and use their potentials for selfsustainability and alleviation of poverty (Ahmed, 2000).

Qureshi, M.I et al (2012) considered the micro credit scheme still a new approach for the poor of Pakistan. Saving power of the poor is very low and only $5 \%$ poor have availed the micro credit facilities in Pakistan. Pakistan is a country where micro credit has a vast potential. Different programs and policies were formulated for the small scale loans by the government for poverty reduction in Pakistan. Micro credit is one of the best among these policies (Nasim et al, 2009). Micro credit is incorporated with self -employment. It has been observed that micro credit has increased the saving power of poor. Micro credit model has remarkably shown good results in economic development (Kazim 2010). Waheed (2009) in his research found micro credit a best tool for poverty reduction and uplifting the life standard of beneficiaries.

Akhuwat is a non-governmental, non-political organization providing micro credit to the rural poor free of interest throughout Pakistan. Akhuwat has 500 branches in 207 cities and towns throughout Pakistan. So far Akhuwat has a total of 1,460,708 benefiting families consisting of 857,260 males and 603,448 females and it has disbursed Rs 28,276,804,342 among these 
beneficiaries with $99.93 \%$ of recovery rate. Akhuwat is providing small loans to the poor without discrimination. Akhuwat has certain objectives which are poverty reduction and selfsustainability. Akhuwat provides loans in collectoral system and changing the borrowers into lenders. Most of the Pakistan's population is living below poverty line. Akhuwat reaches these people and try start the journey of hope with them. Akhuwat provides financial support for their better life. The current study found out that Akhuwat has been proved a best model for micro credit program.

\section{Objectives of the Study}

1. To know about the role of Akhuwat in self-sustainability.

2. To analyze the basic characteristics of the micro credit beneficiaries.

3. To evaluate the level of poverty alleviation due to micro credit provided by Akhuwat.

\section{Questions/Hypotheses}

1 Does micro credit bring sustainability?

2 Does micro credit improve employment status?

3 Does micro credit improve income?

4 Does micro credit fulfill the basic needs of poor?

5 Does micro credit alleviate poverty?

\section{Methodology}

It was a survey type study which focused on the micro credit activity of Akhuwat in Tehsil Nowshera. Akhuwat is a non-governmental organization which provide small loan free of interest to the poor. Information was got through local offices of Akhuwat about the borrowers. Two basic approaches de-jureand and de-fecto were used to collect data from the population. In de-jure approach persons are counted at their usual place of living or residence and in defecto approach persons are counted where they are found at the time of survey or census data collection. In this study de-jure approach was used to collect data from the population and data was tabularized on de-jure basis.

\section{Population}

All the borrowers of Akhuwat in District Nowshera were counted as the population of the study. There was no restriction on gender, race or age.

\section{Sample}

Large sample size is considered best for the accuracy of a research. The researcher preferred small size of sample for better management such as time management, best observation management and financial control. Ten Union Councils were randomly selected. Fifteen borrowers from each Union Council were selected. In this way sample size became 150 borrowers from Tehsil Nowshera.

\section{Instrument}

Questionnaire was constructed on 5 point close ended likevert scale. Questionnaire had two parts $A$ and $b$. Part was about the basic information and characteristics before and after taking the loan. Part B was about the role of micro credit activity of Akhuwat in Tehsil Nowshera. 


\section{Data Collection Procedure}

Before starting data collection process, the researcher had visited many times the local offices of Akhuwat to get information about the borrowers. After getting information and addresses of the respondents, the researcher visited the respondents by local leaders, influential, leaders of prayers and female social workers to established good understanding with respondents. Different introductory meetings and sessions of the researcher with the respondents established pleasant climate for data collection. The researcher awaked and agreed upon the respondents and interview time framework was set according to the convenience of the respondents. It took more than three months to gather the data from the respondents.

\section{Data Analysis}

Collected data was separated according to part and part B. The collected data was encoded and put in by using frequencies and percentages. Inferential statistics Paired T test and Chi Square test were used to find out the result. The coded data was analyzed using SPSS version 17.

\section{Results/Major Findings}

Table 1: Employment opportunities have improved

\begin{tabular}{lcccc}
\hline $\begin{array}{l}\text { Employment } \\
\text { opportunities have } \\
\text { improved }\end{array}$ & Frequency & Percent & Valid Percent & Cumulative Percent \\
\hline Disagree & 8 & 5.3 & 5.3 & 5.3 \\
Neutral & 2 & 1.3 & 1.3 & 6.7 \\
Agree & 9 & 6.0 & 6.0 & 12.7 \\
Strongly agree & 131 & 87.3 & 87.3 & 100.0 \\
Total & 150 & 100.0 & 100.0 & \\
\hline
\end{tabular}

Table 1 indicates that $87.3 \%$ of the borrowers are strongly agreed, $6 \%$ are agreed, $1.3 \%$ are neutral and $5.3 \%$ are disagreed with statement.

Table 2: Standard of the family has improved

\begin{tabular}{lcccc}
\hline $\begin{array}{l}\text { Standard of the family } \\
\text { has improved }\end{array}$ & Frequency & Percent & Valid Percent & Cumulative Percent \\
\hline Disagree & 8 & 5.3 & 5.3 & 5.3 \\
Neutral & 1 & .7 & .7 & 6.0 \\
Agree & 5 & 3.3 & 3.3 & 9.3 \\
Strongly agree & 136 & 90.7 & 90.7 & 100.0 \\
Total & 150 & 100.0 & 100.0 & \\
\hline
\end{tabular}

Table 2 indicates that $90.7 \%$ of the borrowers are strongly agreed, $3.3 \%$ are agreed, $0.7 \%$ are neutral and $53 \%$ are disagreed. 
Table 3: T-Test Pairs Paired Sample Statistics for paired differences (Monthly Income before and after taking loan):

\begin{tabular}{lcccccc}
\hline Monthly income & Mean & SD & SEM & T & df & p \\
\hline $\begin{array}{l}\text { Monthly income before } \\
\text { taking loan Monthly }\end{array}$ & & & & & & \\
income after taking loan & -2.273 & 1.015 & 0.082 & -27.40 & 149 & 0.000
\end{tabular}

Table 3 shows the comparison of monthly income before and after taking loan. It is obvious that monthly income has been increased after taking loan.

Table 4: T-Test Pairs Paired Sample Statistics for paired differences (Employment Status before and after taking loan):

\begin{tabular}{lcccccc}
\hline Status & Mean & SD & SEM & t & Df & $\mathbf{p}$ \\
\hline $\begin{array}{l}\text { Employment Status } \\
\text { before taking loan- }\end{array}$ & & & & & & \\
$\begin{array}{l}\text { Employment Status after } \\
\text { taking loan }\end{array}$ & -0.806 & 0.412 & 0.033 & -23.93 & 149 & 0.000 \\
\hline
\end{tabular}

Table 4 indicates that there is strong change in the employment status after availing the facility of loan. Most of the people have been engaged in self -employments.

Table 5: T-Test Pairs Paired Sample Statistics for paired differences (Capital before and after taking loan)

\begin{tabular}{|c|c|c|c|c|c|c|}
\hline Nature of capital & Mean & S.D & S.EM & $\mathbf{t}$ & Df & p \\
\hline $\begin{array}{l}\text { Capital before taking loan } \\
\text { and Capital after taking } \\
\text { loan }\end{array}$ & -0.993 & 0.798 & 0.065 & -15.237 & 149 & .000 \\
\hline
\end{tabular}

Table 5 shows that the capitals of the respondents have been increased after taking loan.

\section{INFERENTIAL ANALYSIS}

Inferential analysis is concerned with the conclusion and drawings of the data obtained from the population.

Hypothesis No.1: Does micro credit bring sustainability?

$\mathrm{H}_{0}$ : There is no association between role of micro credit activity of Akhuwat and sustainability of the respondents.

$\mathrm{H}_{1}$ : There is no association between role of micro credit activity of Akhuwat and sustainability of the respondents.

Chi square test was applied to determine the association between the role of micro credit activity of Akhuwat and sustainability of the respondents. Operational micro credit support of Akhuwat was taken as independent variable while sustainability of respondents was taken as dependent variable. 
Journal of Business School, vol.1, issue.2, pp.47-59

Table 6: Does micro credit bring sustainability?

\begin{tabular}{lccr}
\hline Variables & Value & df & Asymp. Sig. (2-sided) \\
\hline Pearson Chi-Square & $312.220^{\mathrm{a}}$ & 33 & .000 \\
Likelihood Ratio & 226.504 & 33 & .000 \\
Linear-by-Linear Association & 124.053 & 1 & .000 \\
N of Valid Cases & 150 & & \\
\hline
\end{tabular}

Table 6 indicates that there was a significant relationship between the two variables (Chi square value $=312.22, \mathrm{df}=33$ and $\mathrm{p}=0.000$ which is $<0.05$ ). As $\mathrm{p}<0.05$, so the alternative hypothesis $\mathrm{H}_{1}$ that is there is association between role of micro credit activity of Akhuwat and sustainability of the respondents is accepted. Hence the null hypothesis $\mathrm{H}_{0}$ that is there is no association between the role of micro credit activity of Akhuwat and sustainability of the respondents.

Hypothesis No.2: Does micro credit improve employment status?

$\mathrm{H}_{0}$ : There is no association between role of micro credit activity of Akhuwat and improvement in employment status of the respondents.

$\mathrm{H}_{1}$ : There is no association between role of micro credit activity of Akhuwat and improvement in employment status of the respondents.

Chi square test was applied to determine the association between the role of micro credit activity of Akhuwat and improvement in employment status of the respondents. Operational micro credit support of Akhuwat was taken as independent variable while improvement in employment status of respondents was taken as dependent variable.

Table 7: Does micro credit improve employment status?

\begin{tabular}{lrcr}
\hline Variables & \multicolumn{1}{c}{ Value } & df & Asymp. Sig. (2-sided) \\
\hline Pearson Chi-Square & $171.264^{a}$ & 33 & 0.000 \\
Likelihood Ratio & 85.893 & 33 & 0.000 \\
Linear-by-Linear Association & 61.892 & 1 & 0.000 \\
N of Valid Cases & 150 & & \\
\hline
\end{tabular}

Table 7 shows that there was a significant relationship between the two variables (Chi square $=$ 174.264. $\mathrm{df}=33$ and $\mathrm{p}=0.000$ which is $<0.05$ ). As the level of significance for the calculated value is less than 0.05 , so the alternative hypothesis $\mathrm{H}_{1}$ that is there is association between role of micro credit activity of Akhuwat and improvement in employment status of the respondents is accepted. Hence the null hypothesis $\mathrm{H}_{0}$ that is there is no association between the role of micro credit activity of Akhuwat and improvement in employment status of the respondents.

Hypothesis No.3: Does micro credit improve income?

$\mathrm{H}_{0}$ : There is no association between role of micro credit activity of Akhuwat and improvement in income of the respondents.

$\mathrm{H}_{1}$ : There is no association between role of micro credit activity of Akhuwat and improvement in income of the respondents.

Chi square test was applied to determine the association between the role of micro credit activity of Akhuwat and improvement in income of the respondents. Operational micro credit 
support of Akhuwat was taken as independent variable while improvement in income of respondents was taken as dependent variable.

Table 8: Does micro credit improve income?

\begin{tabular}{lccc}
\hline Variables & Value & df & Asymp. Sig. (2-sided) \\
\hline Pearson Chi-Square & $150.137 \mathrm{a}$ & 33 & .000 \\
Likelihood Ratio & 75.403 & 33 & .000 \\
Linear-by-Linear Association & 64.826 & 1 & .000 \\
N of Valid Cases & 150 & & \\
\hline
\end{tabular}

Table 8 indicates that there was a significant relationship between the two variables (Chi square value $=150.137, \mathrm{df}=33$ and $\mathrm{p}=0.000$ which is $<0.05$ ). As $\mathrm{p}<0.05$, so the alternative hypothesis $\mathrm{H}_{1}$ that is there is association between role of micro credit activity of Akhuwat and improvement in income of the respondents is accepted. Hence the null hypothesis $\mathrm{H}_{0}$ that is there is no association between the role of micro credit activity of Akhuwat and improvement in income of the respondents.

Hypothesis No.4: Does micro credit fulfill the basic needs of poor?

$\mathrm{H}_{0}$ : There is no association between role of micro credit activity of Akhuwat and fulfillment the basic needs of the respondents.

$\mathrm{H}_{1}$ : There is no association between role of micro credit activity of Akhuwat and fulfillment the basic needs of the respondents.

Chi square test was applied to determine the association between the role of micro credit activity of Akhuwat and fulfillment the basic needs of the respondents. Operational micro credit support of Akhuwat was taken as independent variable fulfillment the basic needs of respondents was taken as dependent variable.

Table 9: Does micro credit fulfill the basic needs of poor?

\begin{tabular}{lccc}
\hline Variables & Value & df & Asymp. Sig. (2-sided) \\
\hline Pearson Chi-Square & $146.186^{\mathrm{a}}$ & 33 & 0.000 \\
Likelihood Ratio & 72.558 & 33 & 0.000 \\
Linear-by-Linear Association & 58.198 & 1 & 0.000 \\
N of Valid Cases & 150 & & \\
\hline
\end{tabular}

Table 9 indicates that there was a significant relationship between the two variables (Chi square value $=146.186, \mathrm{df}=33$ and $\mathrm{p}=0.000$ which is $<0.05$ ). As $\mathrm{p}<0.05$, so the alternative hypothesis $\mathrm{H}_{1}$ that is there is association between role of micro credit activity of Akhuwat and fulfillment the basic needs of the respondents is accepted. Hence the null hypothesis $\mathrm{H}_{0}$ that is there is no association between the role of micro credit activity of Akhuwat and fulfillment the basic needs of the respondents. 
Hypothesis No.5: Does micro credit alleviate poverty?

$\mathrm{H}_{0}$ : There is no association between role of micro credit activity of Akhuwat and poverty alleviation of the respondents.

$\mathrm{H}_{1}$ : There is no association between role of micro credit activity of Akhuwat and poverty alleviation of the respondents.

Chi square test was applied to determine the association between the role of micro credit activity of Akhuwat and poverty alleviation of the respondents. Operational micro credit support of Akhuwat was taken as independent variable poverty alleviation of respondents was taken as dependent variable.

Table 10: Does micro credit alleviate poverty?

\begin{tabular}{lccc}
\hline Variables & Value & df & Asymp. Sig. (2-sided) \\
\hline Pearson Chi-Square & $178.568^{\mathrm{a}}$ & 33 & 0.000 \\
Likelihood Ratio & 107.486 & 33 & 0.000 \\
Linear-by-Linear Association & 76.003 & 1 & 0.000 \\
N of Valid Cases & 150 & & \\
\hline
\end{tabular}

Table 10 indicates that there was a significant relationship between the two variables (Chi square value $=176.568, \mathrm{df}=33$ and $\mathrm{p}=0.000$ which is $<0.05$ ). As $\mathrm{p}<0.05$, so the alternative hypothesis $\mathrm{H}_{1}$ that is there is association between role of micro credit activity of Akhuwat and poverty alleviation of the respondents is accepted. Hence the null hypothesis $\mathrm{H}_{0}$ that is there is no association between the roles of micro credit activity of Akhuwat and poverty alleviation of the respondents.

\section{Discussion on Major Findings}

Findings of the study show the activity of Microcredit of Akhuwat has positive relationship with the characteristics of beneficiaries. The giant problem of poverty has been minimized. The social conditions of the beneficiaries have been improved. Saving and purchasing powers have been improved. The beneficiaries have changed their traditional life style and started concerns about their health and hygiene. They planned good education for their children. The employment opportunities have been increased. It can be summarized that microcredit activity of Akhuwat has positively changed the borrowers' life into satisfied life.

\section{Conclusions}

a) Akhuwat provided loans to the needy and poor people.

b) Akhuwat provided loans to the poor at their doorsteps.

c) No other NGOs or CBOs has provided micro credit facility to the people in the area except Akhuwat.

d) Bank of Khyber also provided free of interest loans to the poor in the area but the procedure was very tough as compared to Akhuwat.

e) Akhuwat provided professional on-job training to their borrowers. 
f) Educational status of the people has been improved after availing the micro credit facility of Akhuwat.

g) Micro credit activities of Akhuwat have raised the social status of the people in the area.

h) Most of the people became empowered after availing micro credit facilities of Akhuwat.

i) Akhuwat has raised the saving power of the poor in the area.

j) Akhuwat has raised the standard of life of the people.

\section{Recommendations/Implications of the Study}

a) Akhuwat must be encouraged for its efforts.

b) Government must impart the model of Akhuwat in the country.

c) Micro Finance Institutions and banks must follow the micro credit model of Akhuwat.

d) Governmentof Pakistan must support NGOs and CBOs in micro credit programs.

e) Micro credit programs must be initiated from bottom to top.

f) Institutional training must be provided to the borrowers before sanctioning the loan.

g) Micro credit programs must be embedded with skills.

h) In order to achieve the objectives a proper formative and summative evaluation may be undertaken.

i) Proper feedback must be given to the borrowers like Akhuwat.

j) Strong monitoring programs may be launched so as to get rid of any faults from borrowers or lenders like the collectoral system of Akhuwat.

k) Women must be involved in the micro credit programs on priority basis as pointed out in the present study for their high concerns and repayment of loans.

1) Easy installments of recovery of loans have shown better results, so the recovery process may be made conducive.

m) The Poor showed remarkable potentials for the utilization of loans, so poor people may be prioritized and encouraged towards micro credit programs.

\section{References}

Ahmad, S., Naveed, S.M., \& Ghafoor, A. (2004). Role of Microfinance in Alleviating Rural poverty: a case study of Khushhali Bank Program in Rahim Yar Khan Pakistan.International Journal of Agriculture and Biology, 7: 426428.

Ahmed, U. F. (2000) Micro-credit Financing and Poverty Reduction, Monthly Management Accountant, November-December 2000, Institute of Cost and Management Accountants of Pakistan.

Ali, A. and Thorbecke, E. (2000). ' The state and path of poverty in Sub-Saharan Africa: Micro Finance Journal, Volume 5, No. 2.

Bajwa, R. (2001) Talk given to the Participants of 75th National Management Course, held at Pakistan Administration Staff College, Lahore, Pakistan. 
Bakhshoodeh, M., \& Karami, A. (2008). Determinants of poor accessibility to microcredits in rural Iran. International Conference on Applied Economics.

Basher. (2009). Promotional Role of Microcredit: Evidence From the Grameen Bank of Bangladesh. Hoboken: John Wiley \& Sons Ltd.

Chaudhuri, B. R. (n, d.). Demand and Supply Factors in the Regional Disparity of Micro Credit in India. Indian Institute of Foreign Trade.

Chowdhury, M. J. A. (2009). Microcredit, micro-enterprises, and self-employment of nations.

Delfiner, M., \& Perón, S. (2007). Commercial Banks and Microfinance. Empowerment and Poverty Alleviation of Poor People: A Case Study on Chittagong District of Bangladesh", Umea School of Business (USBE) Master Thesis, Department of Business Administration.

Fernando, J.L. (2008) „Nongovernmental Organizations, Micro-Credit, and Empowerment of Women"e, Annals of the American Academy of Political and Social Science. paper no.554. Pp-150-177. Washington, DC: The World Bank.

Haroon, Jamal. (2008) EXPLORING THE IMPACT OF MICROFINANCE IN PAKISTAN Kieran.

Hoque, Seerajul (2008), "Does Micro credit Programs in Bangladesh Increase Household ability to Deal with Economic Hardships?" Working Paper: Dhaka.

Hussien, M. and Hussain, S. (2003). "The Impact of Microfinance on Poverty andGender Equity: International Conference on Poverty Reduction through Microfinance, held at Cylan Inter-Continental Hotel, Taksim, Turkey from June 9-10, 2003. International Journal of Agriculture and Biology, 7:426 428.

Jamil, A. (2006), 'The development of the most vulnerable in Pakistan. Approaches and Evidence from Pakistan". Pakinstan Gender Report Document: Islamabad.

Kazim, S (2010) Microfinance: integral to economic growth policy Daily Times, January 27, 2010. Kenya's Microfinance Industry Micro-Save Africa.

Khan, M.A. \& Rehman M.K. (2007)," Impact of Microfinance on Living Standards.

Latifee, H.I. (2003). "Microcredit and Poverty Reduction". A Paper presented at the International Conference on Poverty Reduction through Microfinance, held at Ceylan Inter-Continental Hotel, Taksim, Turkey from June 9-10, 2003

Lindvert, M. (2006). “Sustainable Development Work and Micro Finance:

Llanto, G.M. (2003). A microfinance promise: To provide the poor access to finance.

Marr, A. (2004), Challenge to the orthodoxy concerning micro finance and poverty

Mason K., O., Smith H., L., (2003). “Women's Empowerment and Context”

Momoh, J, (2005), "The role of Micro Finance in Rural Poverty Reduction in Developing Countries"

Morduch, J. (2002), Analysis of the Effects of Micro Finance on Poverty Reduction. 
Narayan, Deepa. And patti petesch. (2002).Voices of the poorfrom Mary Land NewYork: Oxford of Social Sciences, Mid Sweden University. Prefiminary results'. Journal of African Economies, 9: 9'40.

Nasim shah shirazi and Aman ullah khan, (2009): “Role of Pakistan Poverty Alleviation Fund's Micro credit in Poverty Alleviation". A Case of Pakistan" Pakistan Economic and Social Review Volume 47, No. 2 (Winter 2009), pp. 215-228 outcomes

Nathaneal, G.(2005). 'Measuring the Impact of Microfinance, Taking Stock of What We Know" Grameen Foundation: USA.

Nawai, N. (2010). Determinants of Repayment Performance in Microcredit Programs: A Review of literature. 1, 2. International Journal of Business and Social Science.

NYU Wagner Workong Paper, No 1014.

Otero, M. \& Rhyne, E. (1999). The New World of Micro Enterprise Finance: Building Healthy Financial Institutions for the Poor. Kumarian Press, New York.

Qureshi, M.I., Saleem, M.A., Shah, M., Abbas, Z., Qasuria, A.W., \& Saadat, U.R. (2012) Ensuring the role and impact: Reaching the poorest while alleviating the poverty by Microfinance. Developing Country Studies ISSN 2224-607X (Paper) ISSN 2225-0565 (Online) Vol. 2 No. 4 Pp 38-44.

SBP-a, (2007), Annual Report for 2006-2007, State Bank of Pakistan. Retrieved on March 15, 2016, from http://swww.sbp.org.pk/reports/annual/arfy07/Chp-8.pdf, p.1-18 .

Seemi, Waheed. (2009), “Does rural microcredit improve well-being of borrowers inthe punjab (Pakistan)?" Pakistan Economic and Social Review. Volume 47, No. 1, pp. 31-47. services. PIDS Policy Notes No. 2003-06.

Sharif, M. (2006),'The Daily News'Article published on,'Poverlry debate': where do we stand?

Shastri, R. k. (2009), “ Micro Finance and Poverty Reduction in India: A Comparative Study with Asian Countries". African Journal of Business Management. Vo; 3(4): 136-140.

Study of how ECLOF Ghana is Working Towards Financial Sustainability". Thesis submitted to the Department of Social Sciences, Mid Sweden University.

Waheed, S. (2009). Does Rural Microfinance Credit Improve Well-Being Of Borrowers in the Punjab (Pakistan). Pakistan economic and Social Review, 47(1), 31-47.

Waheed, S. (2009): 'Does Rural Microfinance Credit Improve Well-Being of Borrowers in the Punjab (Pakistan)'? Pakistan Economic and Social Review, 47(1), 31-47. we stand? University Press.

Yunus M (2006). "Interview - 'Poverty is a Threat to Peace. Extreme Poverty Destabilizes Societies. Microcredit Helps Reduce That Threat."' MacLean's 119(47): 16-17. 